$\mathcal{E}_{\text {Iransport Forum }}^{\text {International }}$

\title{
The National Audit Office's Value-for-Money Assessment of Transport Investments
}

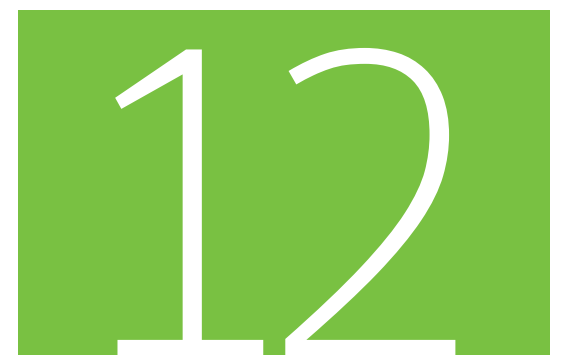

Discussion Paper 2014 • 12

Geraldine Barker,

Grace Beardsley, Annie Parsons

The National Audit Office, London,

United Kingdom 


\title{
International Transport Forum
}

\section{The National Audit Office's Value-for-Money Assessment of Transport Investments}

\author{
Discussion Paper $\mathbf{N}^{\circ}$ 2014-12 \\ Prepared for the Roundtable: \\ Ex-post Assessment of Transport Investments \\ and Policy Interventions
}

(15-16 September 2014, OECD, Paris)

\section{Geraldine BARKER, Grace BEARDSLEY, Annie PARSONS}

The National Audit Office

London

United Kingdom

August 2014 


\section{THE INTERNATIONAL TRANSPORT FORUM}

The International Transport Forum at the OECD is an intergovernmental organisation with 54 member countries. It acts as a strategic think-tank, with the objective of helping shape the transport policy agenda on a global level and ensuring that it contributes to economic growth, environmental protection, social inclusion and the preservation of human life and well-being. The International Transport Forum organises an annual summit of Ministers along with leading representatives from industry, civil society and academia.

The International Transport Forum was created under a Declaration issued by the Council of Ministers of the ECMT (European Conference of Ministers of Transport) at its Ministerial Session in May 2006 under the legal authority of the Protocol of the ECMT, signed in Brussels on 17 October 1953, and legal instruments of the OECD.

The Members of the Forum are: Albania, Armenia, Australia, Austria, Azerbaijan, Belarus, Belgium, Bosnia and Herzegovina, Bulgaria, Canada, Chile, People's Republic of China, Croatia, Czech Republic, Denmark, Estonia, Finland, France, Former Yugoslav Republic of Macedonia, Georgia, Germany, Greece, Hungary, Iceland, India, Ireland, Italy, Japan, Korea, Latvia, Liechtenstein, Lithuania, Luxembourg, Malta, Mexico, Republic of Moldova, Montenegro, the Netherlands, New Zealand, Norway, Poland, Portugal, Romania, Russian Federation, Serbia, Slovak Republic, Slovenia, Spain, Sweden, Switzerland, Turkey, Ukraine, United Kingdom and United States.

The International Transport Forum's Research Centre gathers statistics and conducts co-operative research programmes addressing all modes of transport. Its findings are widely disseminated and support policymaking in Member countries as well as contributing to the annual summit.

\section{Discussion Papers}

The International Transport Forum's Discussion Paper Series makes economic research, commissioned or carried out at its Research Centre, available to researchers and practitioners. The aim is to contribute to the understanding of the transport sector and to provide inputs to transport policy design.

ITF Discussion Papers should not be reported as representing the official views of the ITF or of its member countries. The opinions expressed and arguments employed are those of the authors.

Discussion Papers describe preliminary results or research in progress by the author(s) and are published to stimulate discussion on a broad range of issues on which the ITF works. Comments on Discussion Papers are welcomed, and may be sent to: International Transport Forum/OECD, 2 rue André-Pascal, 75775 Paris Cedex 16, France.

For further information on the Discussion Papers and other JTRC activities, please email: itf.contact@oecd.org

The Discussion Papers can be downloaded from:

www.internationaltransportforum.org/jtrc/DiscussionPapers/jtrcpapers.html

The International Transport Forum's website is at: www.internationaltransportforum.org

This document and any map included herein are without prejudice to the status of or sovereignty over any territory, to the delimitation of international frontiers and boundaries and to the name of any territory, city or area. 


\section{Table of Contents}

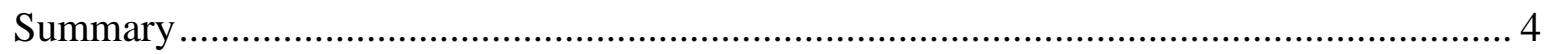

1. The Role of the National Audit Office ............................................................... 6

2. Our Approach to Assessing Value for Money ................................................ 8

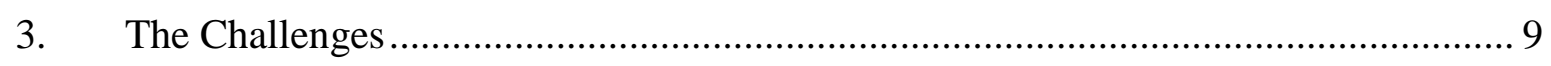

4. Our Recommendations Leading to Improvement .......................................... 13

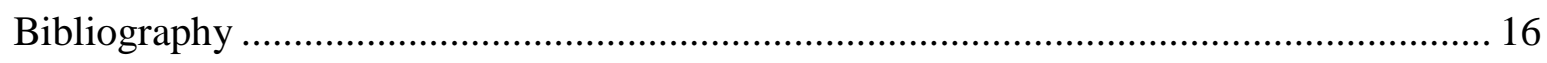

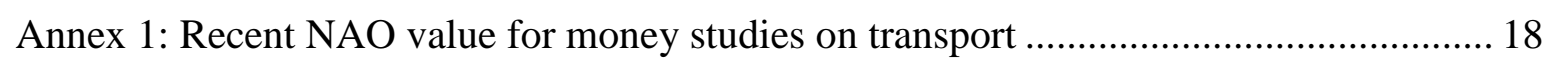

Annex 2: Analytical framework for assessing value for money.................................... 19 


\section{Summary}

The UK National Audit Office (NAO) scrutinises public spending on behalf of Parliament, helping it to hold government departments to account and helping public bodies improve performance and delivery. We publish around 60 value for money studies each year across a range of government activities, of which, around three of these usually cover transport topics. Our reports look at how government projects, programmes and initiatives have been implemented and make recommendations on how it can be improved.

Our value for money work is not strictly ex-post assessment in the usual sense of assessing a programme once it has been in operation for some time. Due to the length of time needed to complete major transport investments and our remit to focus on accountability, we often carry out an assessment of a project before its completion. In some cases, particularly for significant infrastructure investments, a series of value for money reports is appropriate as the programme will develop over time. These tend to focus on how the programme is being delivered, in terms of the planning, procurement or construction phases of infrastructure projects.

We have had cause to comment on the Department for Transport's (the Department) failure to carry out full ex-post assessment of the UK transport projects that we have examined. Ex-post assessments have a valuable role to play in capturing learning and feeding into decision making about current and future projects. Given the long lead times such projects and programmes often have before they deliver their intended benefits, ex-post assessments should be one part of a wider programme of reviews throughout a project or programme's life.

In carrying out our work our three main aims are to:

- Obtain robust evidence and analysis in order to draw sound conclusions about whether the investment of public money provided value for money;

- Address the issues which taxpayers and their elected representatives believe are pertinent in making that assessment;

- Draw out lessons for future programmes both within the transport sector and elsewhere in government.

The first and third of these - the need for robust evidence and the desire to learn for the future clearly have strong parallels in 'classic' ex-post assessment.

We base our work on a standard approach which we apply across the range of central government's activities and services. All our value for money work refers to an analytical framework shown in Appendix 2 of this paper. Audit teams use this framework as a starting point and the basis on which to develop their detailed methodologies. They flex the application of the framework according to the particular topic, applying their professional judgment and experience. The analytical framework examines the economy, efficiency and effectiveness with which resources are used. We also consider factors such as whether the use of resources was optimal and key decisions were reasonable at the time they were taken. 
This paper focuses on four of the most significant and most recurring challenges we encounter when carrying out value for money work in the transport sector:

- Choosing the appropriate point or points at which to assess a programme. We need to balance a number of considerations such as allowing the programme sufficient time to become established, the expectations of our stakeholders for timely evaluation and the scope for our recommendations to influence the programme going forward;

- Evaluating the wider economic impacts of transport investment. Where wider economic impacts are cited as the reason why a transport project is required, decision makers and evaluators have found it hard to quantify these impacts. However, we have seen increasing interest recently in carrying out full ex-post assessments, including effects such as economic growth and regeneration, and using the learning from these to inform approaches to planning and delivering future programmes. For example, the Department for Transport has also published an evaluation strategy and an evaluation and monitoring programme.

- Obtaining and interrogating data and information. While our statutory rights give us unique access to data and documentary evidence, we too face issues of having to make judgments on a programme's success where there is insufficient data or information. We provide an example of how we have used available data to test and validate decisions made; and

- Assessing the impact of government interventions where there are many other factors at play. For example, transport regulatory bodies have some influence on the rate of road accidents through their work to enforce vehicle safety standards but road safety is also influenced by, for example, the weather and drivers' health.

While most of our discussion focuses on the examination of major infrastructure programmes, we also refer to examples of other interventions by government agencies in the transport sector. In assessing such activities we have used techniques such as benefit-cost calculations to conclude on whether agency interventions are value for money.

Our value for money reports contain recommendations for the audited body, however the extent to which they have been implemented is variable. Certain recommendations often recur, such as the robustness of underlying data and quality of risk management. We seek to address this by taking a systematic approach to following up our recommendations, with the aim that the Department and its agencies will increase their focus on these areas and improve performance over time. 


\section{The Role of the National Audit Office}

The work of the National Audit Office is part of the UK accountability process for funds granted by Parliament (Figure 1).

\section{Figure 1: The accountability process}

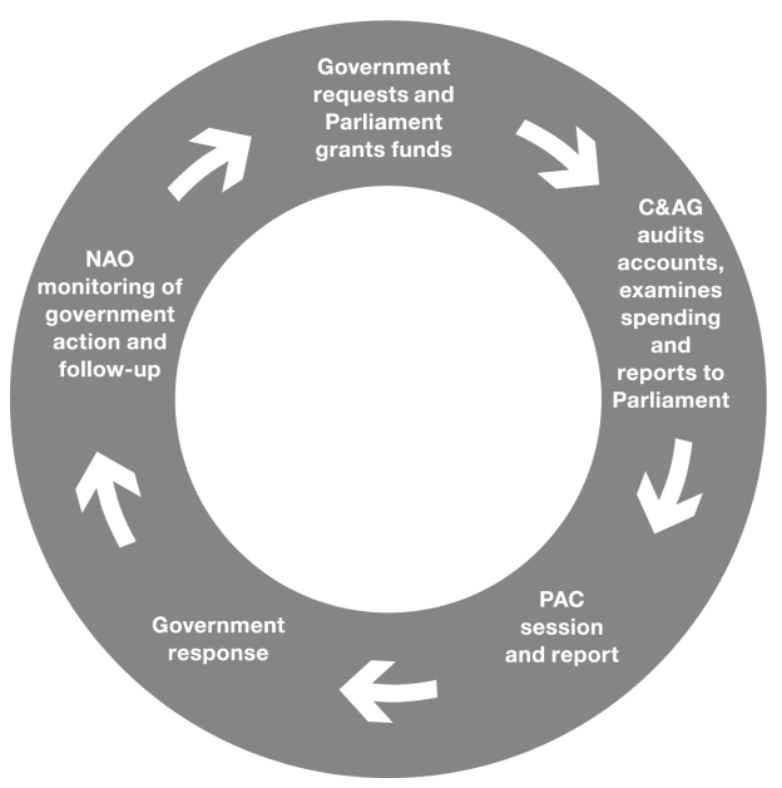

Source: National Audit Office

The National Audit Office is headed by the Comptroller and Auditor General (C\&AG) who has the powers to undertake financial audits of government accounts and value for money audits. We produce around 60 value for money reports each year, across the range of government's activities. Each value for money report will:

- consider the economy, efficiency and effectiveness with which government departments and other public sector bodies have used their resources;

- form a judgment on whether value for money has been achieved; and

- make recommendations on how it could be improved.

Most value for money reports are presented to the Committee of Public Accounts (the Committee) in Parliament. The Committee uses our report as the basis of a hearing at which the Committee will question the government officials responsible about our findings. It subsequently publishes its own reports, including recommendations to which the Government must respond. 
Each year around three NAO reports are published on transport topics (see Appendix 1). Where transport projects or activities are directly funded by the Department for Transport (the Department), we have unique access to conduct value for money audits. We also examine projects which the Department delivers via local government or other partners in the private and third sectors. We select projects and areas of expenditure for audit on the basis of various criteria, including their financial value, strategic importance, level of risk and topicality. Our work in recent years has included:

- Major investments in rail infrastructure, including the construction and sale of the highspeed rail line linking London and the Channel Tunnel ('High Speed 1'), and the setting up of the programme to build a high-speed rail line linking London and northern England ('High Speed 2');

- Major procurements such as the purchase of new trains for intercity services and the 'Thameslink' service across London;

- Operational activities of the Department and its agencies, for example the inspection of heavy goods vehicles by the Vehicle and Operator Services Agency;

- Interventions by the Department, for example its decision in 2009 to terminate the franchise for the East Coast Mainline rail service, held by a private company and subsequently transferred to be run by a public operator;

- Delivering transport improvements at the local level, for example the maintenance of roads by both the Highways Agency and local authorities.

Our reports are not strictly ex-post assessments of the Department's programmes, in the sense of assessing a programme once it is fully in operation, as defined by Campbell and Rozsnyai (2002). We tend to examine major investments before they have been completed and their benefits fully realised, focusing on the planning, procurement and construction phases. This is due in part to the interests of our audience - Parliament and the taxpayer - in holding departments to account for the way they use public money, at a sufficiently early stage to influence the remainder of the programme, and to our aim to help improve performance and service delivery. It is also due to the scale and duration of the programmes that we examine which take many years to come into operation. Of our recent work, our third report on the Channel Tunnel Rail Link, now known as High Speed 1, published in March 2012, most resembles a classic ex-post assessment of transport investment. It involves a reworking of the original business case using available data. We also commented specifically on whether the project had been completed to time and cost and on whether forecasts of passenger demand had been achieved.

Within our reports, when relevant, we have commented on the extent to which the Department has evaluated its transport programmes. In general we have found a lack of ex-post assessment. For example, in our review of the Department's funding of local authority major capital schemes we found that the Department did not enforce requirements for local authorities to evaluate their schemes, and it had received evaluation reports for only two of seven projects which required them. More recently, the Department has taken positive steps. In March 2013, the Department produced a monitoring and evaluation strategy, followed by a document in October 2013 setting out its monitoring and evaluation programme which it will update annually. 


\section{Our Approach to Assessing Value for Money}

Key to our approach is the requirement to conclude on value for money. Our analytical framework (described below and reproduced in Appendix 2) helps us to define value for money and how we will assess it, at the beginning of a piece of work. This will lead ultimately to the value for money conclusion in the published report.

The analytical framework has three key components:

- Establishing exactly what we will examine; ${ }^{1}$

- Identifying what good performance would look like, taking into consideration the environment at the time which could constrain what is achievable; and

- Assessing actual performance against 'what good looks like' to draw conclusions and identify recommendations.

The framework draws on traditional approaches to assessing value for money, examining the:

- Economy with which resources are used;

- Efficiency of the relationship between the output of goods, services or other results and the resources used to produce them; and

- Effectiveness, i.e. the relationship between the intended results and the actual results of the projects, programmes and services.

The value for money conclusion, included in all of our value for money reports, is the C\&AG's view on how well resources have been used to achieve particular objectives. It is usually founded on some type of comparative assessment such as cost-benefit analysis where we evaluate the net benefits of a programme against a counterfactual; performance benchmarking against appropriate comparator programmes, or comparison to a model of good practice. There are times when there is insufficient information to conclude on value for money. In these cases, we may decide how far the audit body is at fault, or whether data limitations are a feature of the environment in which the body operates.

1 We may choose to examine the objectives and rationale for the programme; progress in delivering the programme to time and budget; and looking forward, whether risks to delivering the next stage of the programme are being managed effectively. This includes whether the Department is collecting the information and establishing the baselines to enable it to conduct ex-post assessments in the future. 


\section{The Challenges}

There are a number of specific issues related to transport investments and projects which present us with challenges when conducting our value for money assessments and could also present problems for ex-post assessments. We discuss these further below, with reference to case examples taken from our reports. The issues and case examples we will cover include:

- Determining when is the right time to assess the value for money of a programme:

- Department for Transport: The completion and sale of High Speed 1

- Department for Transport: High Speed 2;\

- Evaluating whether wider economic impacts have been achieved:

- Department for Transport: The completion and sale of High Speed 1;

- Making an assessment when there is insufficient data or documentary evidence:

- Department for Transport: The InterCity East Coast Passenger Rail Franchise;

- Assessing the impact of an intervention when there are other factors and agencies at play:

- Vehicle and Operator Services Agency: Enforcement of regulations on commercial vehicles

- Determining when is the right time to assess the value for money of a programme.

It takes time to construct major transport projects and bring them into service. For example, the Crossrail service which is currently being constructed east-west across London will open fully in 2019 , ten years after construction began in 2009. Phase 1 of High Speed 2, a new rail link from London to northern England, is expected to be operational in 2026, some 14 years after the department's decision to go ahead with the project. When considerable sums of public money are spent there is a natural desire to establish whether that expenditure is worthwhile. Crossrail will cost $£ 14.8$ billion, while High Speed 2 is expected to cost around $£ 42.6$ billion $^{2}$. Our key stakeholders are eager for information to inform other projects and are not inclined to wait for a full ex-post assessment (which might be many years hence).

Our challenge is to establish at what point an NAO assessment will be most valuable. We are now taking the approach of examining the Department's most significant programmes at key stages during their initiation, development and delivery. This enables the Department to address the risks and issues we identify at an earlier stage. We talk more about this in Part III of this paper. For example we first examined High Speed 1 in 2001, focusing on the financing of the project. We returned to the topic in 2005, reviewing progress in construction and revised expectations for public funding and in 2012 to report on the completion of the programme and the sale of the operating company, High Speed One Limited.

$2 \quad £ 42.6$ billion is the cost of both Phase 1 and Phase 2 of High Speed 2. 
We are adopting a similar approach to High Speed 2, a programme to develop a new high-speed rail network between London, the West Midlands, Manchester and Leeds. The Department for Transport took the decision to develop Phase 1 of the scheme in January 2012 and the line is expected to be operational in 2026. We published our first report in May 2013, on the Department for Transport's progress in putting in place the foundations for successful programme delivery, examining specifically:

- the Department's case for building a high-speed railway;

- the Department's cost estimate for Phase 1 of the programme, between London and the West Midlands and its assessment of the programme's affordability; and

- how the Department has set up the programme.

We evaluated the Department's performance against the key elements of success which we had identified in our Guide to Initiating Successful Projects, which is based on our experience of 40 major government projects. We examined specifically whether:

- the programme had a clear rationale and objective. We concluded that the Department had poorly articulated the strategic case for high-speed rail;

- the programme was well costed and affordable. We concluded that cost estimates were at an early stage and there were risks to affordability;

- plans for programme delivery were realistic and feasible. We concluded that the timetable for planning phase one, from London to the West Midlands, was challenging; and

- roles and governance arrangements were clear. We concluded that there were weaknesses in programme management which the Department was taking steps to improve.

During the construction phase of a project we would typically examine a major programme once a key stage had been completed, looking in more depth at issues such as whether the programme is being delivered on time and within budget; and whether risks to delivery are being effectively managed. Our recent reports on Thameslink and Crossrail are examples of such examinations.

Even when the project is completed and is operational an issue remains for us as to when our final and, in effect, ex-post assessment should be carried out, as it can take years for the full benefits to be realised. However experience has shown that some of the information that we need for our assessment, particularly on costing is most likely to be available shortly after the completion of the project.

Our March 2012 report on the completion and sale of High Speed 1 included a cost benefit analysis which involved reassessing the costs and journey time saving benefits of the project. The analysis enabled us to determine the likely benefits and costs to the taxpayer. We made the following conclusion which illustrates the difficulties in drawing a value for money conclusion at this stage:

In assessing whether a project will deliver value for money, the Department considers a wide range of impacts that a project might have, some of which it can quantify and others on which it has to make more qualitative judgements. The original business case in 1998 was based on benefits to transport users, from faster journey times and increased rail capacity, and regeneration benefits. The data available only allows us to estimate that the value of journey time savings benefits, over a 60-year appraisal period to 2070, would be $£ 7,000$ million. We estimate that the net costs to the taxpayer to 2070 would be $£ 10,200$ million. On these measures we would conclude that the project is not value for money. When including other impacts from the project, some of which are unmeasurable, we accept that such a clear conclusion is not possible. The Department, however, would need to demonstrate 
that these benefits are going to be at least $£ 8,300$ million, giving a higher contribution than originally expected, to achieve the benefit-cost ratio of 1.5 to 1 estimated in 1998.

At the time of publishing the report in March 2012, the Department was developing a plan to evaluate the High Speed 1 project. The Department's view was that a robust assessment of transport benefits from the high speed line could only be made after December 2012, three years after the introduction of the domestic high speed services. This was based on standard industry demand forecasting guidance which states that the expected change in demand would be complete three years after a major service change, with the majority of change occurring by the end of the first year. However, we believed and stated that the Department should already have had an evaluation plan in place which identified the data it needed to collect and monitor to measure project benefits. We acknowledged that the Department had started work to identify the method it would use to evaluate wider economic impacts and regeneration benefits and how it would establish a counterfactual. We felt however that there was a risk that the Department would not be able to measure robustly the impact of the project because it was not able to demonstrate that it had collected the information it would need. The Department is currently carrying out its evaluation of the project, and a report is expected to be published in 2014.

\section{Evaluating whether wider economic impacts have been achieved}

One of the challenges for both ex-ante and ex-post assessments of transport projects is the measurement of wider economic impacts. This is illustrated by the High Speed 1 programme. The main project benefits the Department identified in 1998 were benefits to transport users, from faster journey times and increased passenger rail capacity, and regeneration benefits. The Department chose to route the line through east London to stimulate regeneration. Including a monetary value for regeneration was unconventional for a public transport project at the time because the Department did not have an agreed method for calculating such benefits. The Department's approach for other projects such as Thameslink, Crossrail and High Speed 2 has been to base the initial benefit cost ratio on the transport benefits and to then produce an additional benefit cost ratio which includes an assessment of wider economic impacts. In the case of High Speed 1 it valued the expected regeneration benefits based on the 50,000 jobs that it originally estimated the line would create at sites around the three international stations, and the amount that the Government would be prepared to pay to create these jobs through other interventions.

When we examined the project in 2012, we found that London and Continental Railways (who delivered the project) had commissioned analysis of the approved developments at all three locations and estimated they would support at least 70,000 jobs. The Department had yet to review the regeneration benefits and told us that they intended to do so after the 2012 Olympic Games, when the legacy plan for the Olympic Park had been implemented. This was because the high speed line has a station at Stratford, where the Olympics took place. Under its transport analysis guidance the Department would need to identify the impact, for example, on unemployment in areas served by the high speed line to quantify regeneration benefits. The Department told us that these impacts are not as easy to isolate as the impact on transport benefits, where the Department already collects data, and a specific study would be required to assess the wider economic and regeneration benefits.

As can be seen in paragraphs 26 and 27 above we did not attempt to quantify the wider economic impacts ourselves, but used our reworking of the cost benefit analysis to show the scale of benefit needed if the project was to deliver value for money. 
It appears to us that in the UK there is an increasing interest in ex-post assessments and in making investment decisions using benefit-cost ratios which capture the full benefits of the project. For the latter, this involves having a better understanding of the wider impacts that infrastructure projects such as those in transport generate. For example, the July 2014 the Committee of Public Accounts report on Crossrail recommended that the Department should improve its understanding of the wider economic benefits of transport projects and include this in its investment decisions. The Department told the Committee that it agreed it needed to do more work on understanding wider economic benefits, such as changing land use, since these could not currently be quantified in the benefit-cost ratio.

\section{Making an assessment when there is insufficient data and documentary evidence}

The availability of data will usually determine what methods we use and the focus of the report. While we can carry out or commission primary research, in the transport sector we generally analyse existing datasets held by the Department, regulatory bodies or other stakeholders such as the rail infrastructure manager, Network Rail. These datasets vary in their complexity, completeness and comparability, and we plan our work taking into account their limitations.

In 2011, we published a report which examined the Department's decision to terminate the InterCity East Coast franchise, in response to the National Express Group stating that it would no longer financially support the franchisee, National Express East Coast. We wanted to determine whether the Department's decision to terminate the franchise offered better value for money than renegotiating the terms of the contract with National Express or negotiating a consensual exit from the contract. The Department had not carried out this analysis and believed that relaxing contract terms would have encouraged the operators of other rail franchises to seek similar deals, exposing the taxpayer to increased costs. The Department's data was not held in a way that would easily allow analysis of the available options which were to renegotiate the terms of the franchise with the operator; negotiate a consensual exit; or terminate for contract default. We therefore drew together the Department's data on the actual and forecast financial performance of train operators facing financial difficulties, and adjusted the data so that it was comparable. We used this evidence to develop a financial model that allowed us to calculate the potential costs to the taxpayer of the three options available to the Department. The analysis helped to support our overall value for money conclusion that the Department's decision to terminate the franchise was the best means of protecting the taxpayer, when compared to other potential options.

\section{Assessing the impact of an intervention when there are other factors and agencies at play}

A challenge in assessing the operations of government transport agencies is attributing ultimate outcomes to their activity. For example, a number of factors contribute to road safety. Although the Vehicle and Operator Services Agency's work (described below) had an impact on road safety, there are many other factors and agents other than the Agency which affect the rate of road accidents, including weather patterns, economic growth rates, drivers' health and drivers' behaviour patterns.

In January 2010, we published a report which examined the work of the Vehicle and Operator Services Agency (VOSA). Until its replacement by the Driver and Vehicle Standards Agency in April 2014, VOSA was the executive agency of the Department for Transport which was responsible for ensuring that Heavy Goods Vehicles (HGVs) and Public Service Vehicles (PSVs) complied with a wide variety of roadworthiness and traffic regulations covering physical maintenance, weight limits and drivers' hours. We wanted to determine whether the benefits from the Agency's enforcement activities met its costs. One aspect of our methodology was to conduct a benefit-cost calculation of its 
enforcement work. This enabled us to conclude that the benefits are likely to exceed the Agency's expenditure, but in our opinion it could deliver significantly better value for money. To carry out our assessment, we:

- estimated the proportion of vehicles with defects for which the Agency checks that go on to cause accidents;

- used this to estimate the number of accidents prevented by VOSA's inspections;

- estimated the average benefit of preventing an accident involving an HGV; and

- applied this to the number of accidents prevented by VOSA's activities to estimate their value to the economy.

We calculated that if the Agency's roadside checks prevented 283 accidents and the average value of each of these was $£ 143,529$, the roadside checks would have delivered $£ 40.7$ million of benefits. This compares to the Agency's expenditure of $£ 32.9$ million on HGV enforcement in 2008-09. We also performed sensitivity analysis by varying the number of accidents prevented by the Agency and the average benefit of a prevented accident by up to $+/-50$ per cent and then looking at the effect different combinations of these changes had on the benefits delivered by roadside checks. This suggested that roadside checks could deliver a minimum of $£ 10$ million and a maximum of $£ 91$ million benefits. The benefit exceeded the Agency's expenditure in 2008-09 in 44 per cent of the combinations analysed.

This assessment enabled us to conclude that the benefits are likely to exceed the Department's expenditure and the result was included in our value for money conclusion on VOSA's enforcement activities. The conclusion, which found that the Agency had achieved 'satisfactory results' also highlighted other issues such as the potential to improve value for money through system improvements such as staff deployment, better location of the sites for checking vehicles and closer working with the Department. This example also serves to illustrate how our value-for-money conclusions take account of multiple aspects to reach an overall judgment. Benefit-cost or other quantitative analysis plays an important part but is not the whole picture.

\section{Our Recommendations Leading to Improvement}

Although our assessments are not strictly ex-post evaluations, our value for money reports include a number of recommendations for the audited body. As explained earlier, the Committee of Public Accounts will use our reports as the basis of a hearing to question the government officials responsible and subsequently publish its own report. Its report will also contain recommendations which the Department must respond to and a summary of its response is made public in HM Treasury's Treasury Minutes.

In our reports on major transport projects, the recommendations generally address the same areas identified by De Jong et al. (2013): 
- Improvement of cost and benefit estimation approaches;

- Risk management measures;

- Increasing accountability; and

- Clarifying project scope and objectives.

Some examples of how we have addressed these themes include:

- Improvement of cost and benefit estimation approaches: Our recommendations in this area have focused on the Department's work in ensuring and making more transparent the robustness of its cost benefit analysis.

- Our March 2012 report on High Speed 1, recommended that the Department ensures its demand forecasts, which feed into the benefit cost estimation, are subject to rigorous scrutiny and scepticism. We also recommended that it should assess the benefits under a range of different scenarios, perform a sensitivity analysis of key assumptions and a sense check to understand the reality of meeting forecast demand. In the November 2012 Treasury Minutes, the Department stated that it now takes greater account of downside risks, and typically undertakes extensive sensitivity analysis to test the robustness of the business case to varying input assumptions.

- Our May 2013 report on High Speed 2 highlighted a number of issues with the calculation of the benefit cost ratio in the economic case including errors in earlier calculations, the need to update the data underpinning key assumptions and the lack of analysis of the effect of premium pricing on forecast passenger demand. The revised business case in October 2013 did seek to address some of these concerns by updating some of the data and revising some assumptions for example around journey time savings, and by quoting the benefit cost ratio as a range rather than point estimates to recognise explicitly the uncertainty of the economic case.

- Risk management measures: The importance of risk management was particularly evident in our examination of the failure of Metronet in 2009. Metronet was a private infrastructure company responsible for the maintenance and upgrade of sections of the London Underground. It went into administration in July 2007. Although Transport for London (TfL) had guaranteed 95 per cent of Metronet's borrowing, the Department had also informally given assurances to investors that it would guarantee the borrowing ${ }^{3}$. When Metronet failed, the Department had to make a grant payment of $£ 1.7$ billion to help London Underground purchase Metronet's debt obligations, a sum that would otherwise have been repaid over the 30 year life time of the contracts. The Department was exposed to this risk but lacked direct ways of gaining assurance over the management of the risk. ${ }^{4} \mathrm{We}$ advised that the Department should: collect and analyse a range of financial and performance data held by parties to the contract or available independently; request regular risk reports from London Underground and TfL as the contracted clients; and review the devolved body's understanding of the key risks to the project to allow it to identify and investigate any issues relevant to the management of its own risk.

3 The Department provides a grant to TfL. London Underground is a subsidiary of TfL.

$4 \quad$ Under the Greater London Authority Act 1999, strategic and investment responsibility for London Underground was devolved to TfL and the Mayor of London. The Secretary of State of the Department could only direct the Mayor to make changes to transport strategy where it would be inconsistent with national policy and have an adverse effect outside London. DfT was not a party to the contracts and had no direct influence over performance. 
- The quality of the Department's oversight of large programmes is an issue which we continue to examine. For example, our recent report on Crossrail commented favourably on the Department and Transport for London's oversight of that programme, highlighting the use of a probability-based approach to forecasting the delivery date and final cost, and to monitor and manage risks which allows the sponsors and Crossrail Limited to identify when there are risks to delivery and to take action to mitigate those risks.

- Increasing accountability: In our December 2012 report on the cancellation of the InterCity West Coast franchise competition, we found that staff in the project team reported to different parts of the organisation which meant no one person oversaw the whole process, or could see patterns of emerging problems. We recommended the Department appoint someone with sufficient seniority to oversee each significant commercial transaction and major project, with the knowledge, skills and the authority in the Department to take action if things are going wrong. The Department has since taken action to review its existing Senior Responsible Owners (SROs) to ensure they have the right seniority, experience and expertise for the projects for which they are currently responsible. Additionally, it has provided training for SROs to ensure they fully understand their responsibilities.

- Clarifying project scope and objectives: As can be seen in paragraph 23 above, one of our criticisms of the early preparations for High Speed 2 was the Department's poor articulation of its strategic case for the route. The Committee of Public Accounts subsequently called for the Department to publish detailed evidence which clearly showed why it considered High Speed 2 to be the best option for increasing rail capacity into London, improving connectivity between regional cities and rebalancing the economy. The Department sought to address the Committee's concerns in its revised strategic case for the project in October 2013.

The extent to which recommendations are implemented has varied and in recent years we have sought to address this by following up implementation more systematically. As can be seen in paragraph 39 above, some issues such as the robustness of underlying data for business cases and the quality of risk management are recurring themes in our work. By returning to these themes, we hope to increase focus on them within audited bodies and raise standards over time. Moreover, where we have conducted early examinations of programmes, we examine specifically in subsequent reports whether earlier recommendations have been implemented. One example of this is our final report on High Speed 1 in May 2012, in which we commented that the Department had not yet reassessed the project costs and benefits since 2001 despite making a commitment to the Committee of Public Accounts to do so. 


\section{Bibliography}

Campbell, C. \& Rozsnyai, C., 2002, Quality Assurance and the Development of Course Programmes. Papers on Higher Education Regional University Network on Governance and Management of Higher Education in South East Europe Bucharest, UNESCO.

Comptroller and Auditor General (all reports available at www.nao.org.uk):

July 2014, Department for Transport: Procuring new trains, Parliamentary Session 2014-15, HC 531

June 2014, Department for Transport and Highways Agency: Maintaining strategic infrastructure: roads, Session 2014-15, HC 169

May 2013, Department for Transport: High Speed 2: A review of early programme preparation, Session 2013-14, HC 124

December 2012, Department for Transport: Lessons from cancelling the InterCity West Coast franchise competition, Session 2012-13, HC 796

October 2012, Department for Transport: Funding for local transport: an overview, Session 2012-13, HC 629

March 2012, Department for Transport: The completion and sale of High Speed 1, Session 2010-2012, HC 1834

December 2011, Guide: Initiating successful projects

March 2011, Department for Transport: The Intercity East Coast passenger rail franchise, Session 2010-2011, HC 824

June 2010, Department for Transport: Increasing passenger rail capacity, Session 2010-11, HC 33

January 2010, Vehicle and Operator Services Agency: Enforcement of regulations on commercial vehicles, Session 2009-2010, HC210

June 2009, Department for Transport: The failure of Metronet, Session 2008-2009, HC 512

July 2005, Department for Transport: Progress on the Channel Tunnel Rail Link, Session 2005-2006, HC 77

March 2001, Department of the Environment, Transport and the Regions: The Channel Tunnel Rail Link, Session 2000-2001, HC 302. 
De Jong et al. (2013), How to Build Major Transport Infrastructure Projects within Budget, in Time and with the Expected Output; A Literature Review, Vol. 33, Issue 2, pp. 195-218.

Department for Transport:

October 2013, Monitoring and Evaluation Programme;

March 2013, Monitoring and evaluation strategy

HM Treasury (all reports available at: www.gov.uk/government/collections/treasury-minutes):

May 2013, Treasury Minutes, Cm 8613, pages 34-38;

November 2012, Treasury Minutes, Cm 8467, pages 25-29.

House of Commons Committee of Public Accounts, July 2014, Crossrail, Eighth Report of Session 2014-15, HC 1062

National Audit Office, May 2011, Department for Transport: Local Authority Major Capital Schemes 


\section{Annex 1 \\ Recent NAO value for money studies on transport}

All reports available at www.nao.org.uk:

- Procuring new trains (July 2014);

- Maintaining strategic infrastructure: roads (June 2014);

- Crossrail (January 2014);

- Progress in delivering the Thameslink programme (June 2013);;

- High Speed 2: a review of early programme preparation (May 2013);

- Lessons from cancelling the InterCity West Coast franchise competition (December 2012); ;

- Funding for local transport: an overview (October 2012);

- The completion and sale of High Speed 1 (March 2012);

- Reducing costs in the Department for Transport (December 2011);

- Local Authority Major Capital Schemes (May 2011);

- Regulating Network Rail's efficiency (April 2011);

- The Intercity East Coast passenger rail franchise (March 2011);

- Procurement of the M25 private finance contract (November 2010);

- Increasing passenger rail capacity (June 2010);

- Highways Agency: Contracting for Highways Maintenance (October 2009);

- The Department for Transport: The failure of Metronet (June 2009). 


\section{Annex 2 \\ Analytical framework for assessing value for money}

The framework below is a key reference source for NAO auditors scoping and planning Value for Money work. It provides a guide to the types of questions we will need to answer to draw clear Value for Money conclusions on topics across the range of government activities. The framework is necessarily broad and acts as a foundation for the development of audit teams' work. Its application to a particular topic will be informed by auditors' professional judgment and experience. Neither this nor any other tool can provide a simple, 'mechanical' conclusion on value for money. 


\section{Analytical framework for assessing Value for Money}

"Good value for money is the optimal use of resources to achieve the intended outcomes."

The objective of our VFM work is to form a clear judgement on whether value for money has been secured in the area under examination. This analytical framework is designed to help teams do this in a consistent manner.

At planning stage teams should follow Steps $A$ and $B$ as set out on page 2 . Having outlined the focus of the report, it is essential to define at this stage what the comparators of good performance will be for each of the study elements. This is crucial not only for a consistent logic of the report, but also to determine how we will measure performance. It also forces us to critically assess what we think possible. Our definition of VFM refers to 'optimal' use of resources - in practice, defining and securing 'optimal VFM' is inherently difficult and often impossible. Therefore, teams are encouraged to establish for each of their evaluative study elements what 'good' would look like in the particular circumstances in 'place' (assisted by the comparator matrix, page 4).

During fieldwork teams will capture the totality of resources relevant to the subject being examined (Step C), as well as all the relevant processes and outputs/outcomes achieved (Step D). This is the stage in the process where we identify data gaps, test causation as well as leam about wider aspects of the environment in which the client operates which might constrain what is achievable (Step E). All those issues have a considerable impact on the type of conclusion we can draw in due course.

When analysing the evidence, teams should in Step $F$ refer to their previously identified comparators of good performance (Step B) and contrast observed performance with what - under the given circumstances - could reasonably have been expected. This always involves assessing and then concluding on a given level of performance in the context of the resources used to achieve this (analysing, as appropriate, economy, efficiency or effectiveness). During this step teams should refer to the Guide on Drawing and Drafting VFM Conclusions.

Having identifled where the weaknesses in performance and arrangements lie, teams can then make robust recommendations designed to improve value for money (Step G) 
Analytical framework for assessing Value for Money

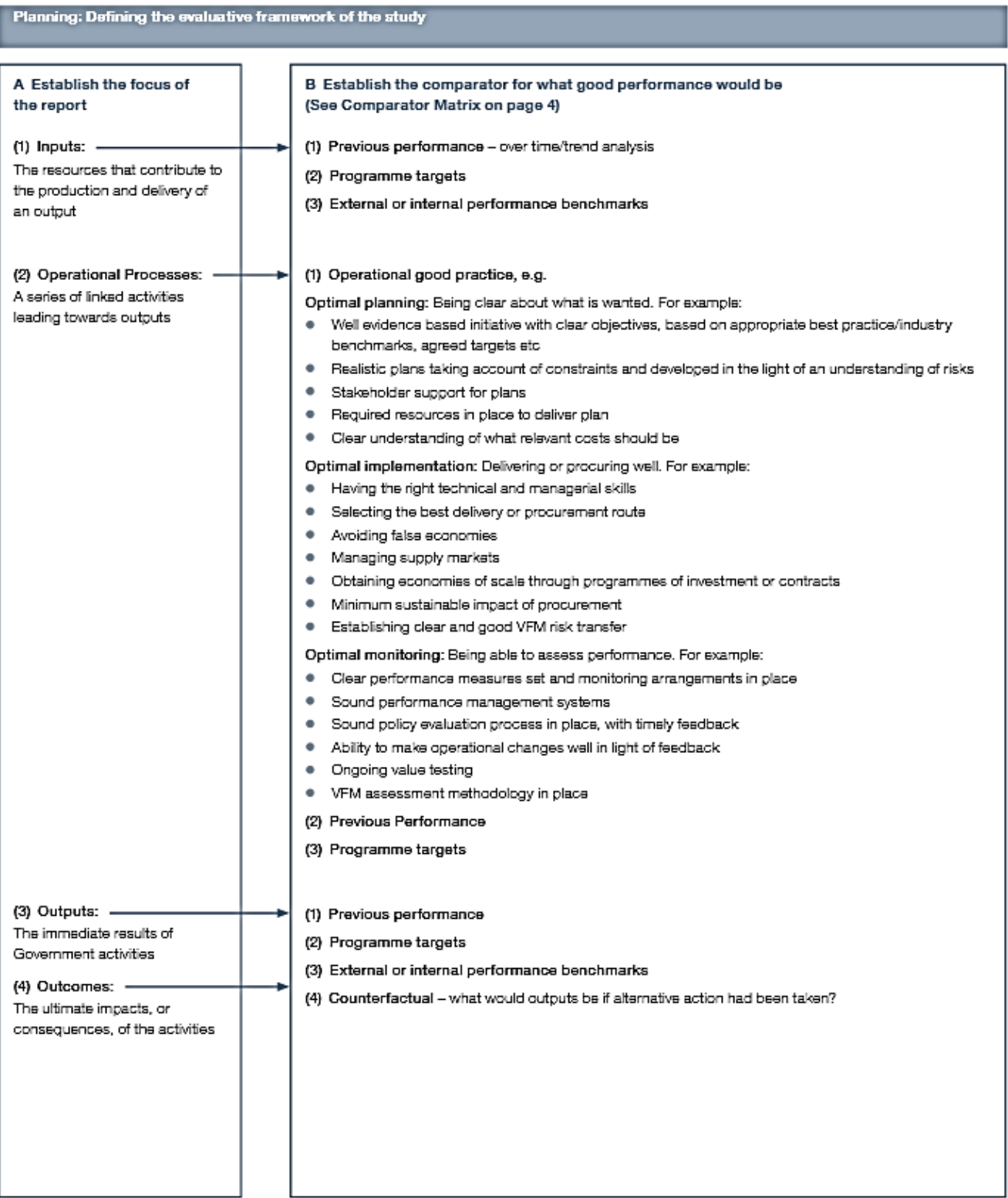

2

Geraldine Barker et al. — Discussion Paper 2014-12 — @ OECD/ITF 2014 


\begin{tabular}{|c|c|}
\hline \multicolumn{2}{|c|}{ Fieldwork: Capturing Casts a } \\
\hline 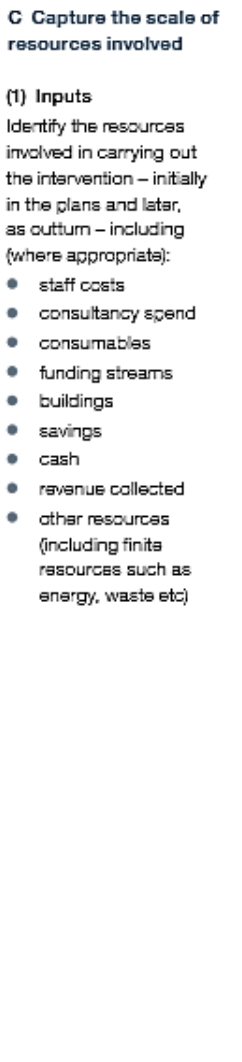 & 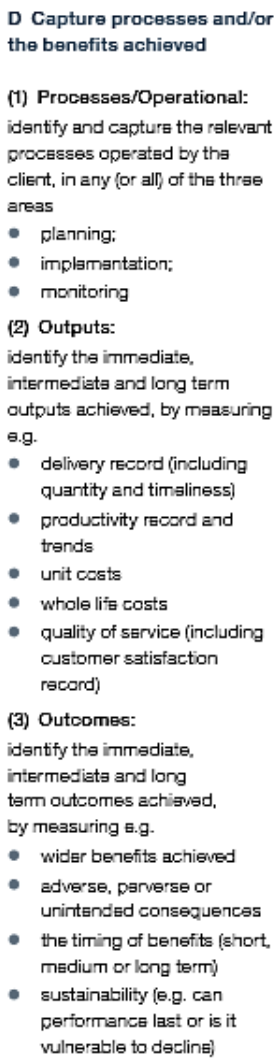 \\
\hline & \\
\hline $\begin{array}{l}\text { E While capturing resource } \\
\text { (outputs and/or outcomes). } \\
\text { - Evidenca/data gaps } \\
\text { - Uncertainty: what are } \\
\text { dats? } \\
\text { - Economy (inputs par } 5 \\
\text { effectiveness (outcom } \\
\text { - Causality: consider wh } \\
\text { outputs and outzomes }\end{array}$ & $\begin{array}{l}\text { and uncertainties ralating to the } \\
\text { cy (outputs per inputs) and/or } \\
\text { tput) } \\
\text { reasonable to suppose that } \\
\text { llly linksd to the initiative or policy }\end{array}$ \\
\hline
\end{tabular}

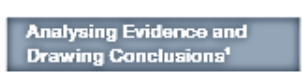

\section{F Draw an overall}

conclusion on value for

money achieved

Having identified and captured

the client's proceeses and/

the client's procesess and/
or achisved parformance (D)

and the resources imolved

(C) in achieving this, compare

this with what was or could

reasonably have been

Expectad in the

circumstances (B):

- Assessing performance:

Compared to the previously

identifiad 'good performance'

comparators (eoth costs

comparators (Eoth costs

they do?

Wers the beneits achiened

worth it giver the scale of

spand/the effort involyad

Spand/the Eifort involisad

apoortunity costs)?

- Considering the context

Given certain constraints

outside the client's control,

what could raasonably have

been expectad?

- Quantification:

How much better could they

have done/did thef do?

(
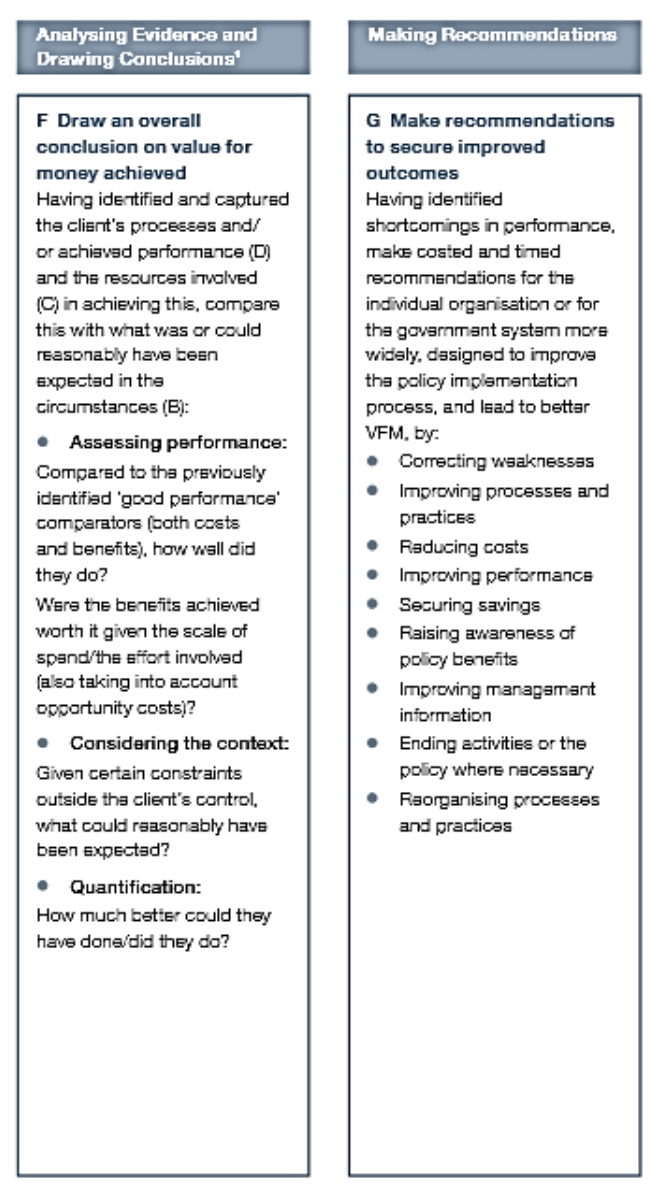

1 See gulde 'Drawing and drafting VFM conclusions' for more detall. 
Analytical framework for assessing Value for Money

\section{Comparator Matrix}

The matrix below illustrates what types of comparator are generally suitable for assessing the performance of particular aspects of a policy/programme.

Teams should use this matrix during study planning to think through systematically how the VFM of the different aspects of their study are going to be assessed. The types of comparator used will determine what type of conclusion we can draw (see Guide on Drawing and Drafting VFM Conclusions, for more detail about different types of conclusions).

\begin{tabular}{|c|c|c|c|c|c|c|c|c|}
\hline & \multirow{3}{*}{ Relattve to } & \multicolumn{6}{|c|}{ Element(s) of performance analysed } & \multirow{3}{*}{$\begin{array}{l}\text { Type of } \\
\text { conclusion }\end{array}$} \\
\hline & & \multirow{2}{*}{$\begin{array}{c}\text { Inputs } \\
\text { [Economy] }\end{array}$} & \multicolumn{3}{|c|}{ Processes/Operational: } & \multirow{2}{*}{$\begin{array}{c}\text { Outputs } \\
\text { [Efnclency] }\end{array}$} & \multirow{2}{*}{$\begin{array}{l}\text { Outcomes } \\
\text { [Etfectlveness] }\end{array}$} & \\
\hline & & & Planning & Implementation & $\begin{array}{l}\text { Monltoring } \\
\text { pertormance }\end{array}$ & & & \\
\hline \multirow{8}{*}{$\begin{array}{l}\text { Comparator } \\
\text { applled } \\
\text { (specify how } \\
\text { thls wlll be } \\
\text { assessed/ } \\
\text { measured) }\end{array}$} & $\begin{array}{l}\text { 'altemative } \\
\text { acton' } \\
\text { coumterrsctus }\end{array}$ & $x$ & - & - & - & $x$ & $\mathrm{x}$ & TypeA \\
\hline & $\begin{array}{l}\text { 'do notring' } \\
\text { counterrsctual }\end{array}$ & $x$ & - & - & - & - & $\mathrm{x}$ & TypeA \\
\hline & $\begin{array}{l}\text { external } \\
\text { benchmarks }\end{array}$ & $\mathrm{x}$ & - & - & - & $x$ & $\mathrm{x}$ & Type в \\
\hline & $\begin{array}{l}\text { Internal } \\
\text { benchmarks }\end{array}$ & $x$ & - & - & - & $x$ & $\mathrm{x}$ & Type в \\
\hline & $\begin{array}{l}\text { programme } \\
\text { targets }\end{array}$ & $x$ & - & - & - & $x$ & $\mathrm{x}$ & Type в \\
\hline & $\begin{array}{l}\text { previous } \\
\text { pertormancs }\end{array}$ & $x$ & $\mathrm{x}$ & $x$ & $\mathrm{x}$ & $x$ & $\mathrm{x}$ & Type в \\
\hline & $\begin{array}{l}\text { operational } \\
\text { good prastlog }\end{array}$ & $x$ & $\mathrm{x}$ & $x$ & $\mathrm{x}$ & - & - & Tyoe c \\
\hline & $\begin{array}{l}\text { Insumiticlent data } \\
\text { to alow for } \\
\text { assessment }\end{array}$ & $x$ & $\mathrm{x}$ & $\mathrm{x}$ & $\mathrm{x}$ & $x$ & $\mathrm{x}$ & Type 0 \\
\hline
\end{tabular}

For example, if we are examining the procurement processes of a Department we can either assess them by comparison with an established set of good practice criteria, or (if the processes have previously been assessed) we can comment on whether their monitoring regime has improved over time (or both). If we assessed the outputs of those procurement processes, we could compare them with the Department's output targets, contrast outputs over time $\alpha$ compare the performance of different units of the Department. For a more objective, 'stronger' assessment of performance, we could contrast performance with that of comparable extemal organisations. 
